\title{
Soil properties and nutrition status of weakened Norway Spruce stands in the Śnieżnik Massif of the Polish Eastern Sudety Mountains
}

\author{
Kazimierz Januszek ${ }^{1, *}$, Stanisław Małek ${ }^{1}$, Ewa Błońska ${ }^{1}$ \\ 1 Department of Ecology and Silviculture, Faculty of Forestry, University of Agriculture in Kraków, Al. 29 listopada 46, \\ 31-425 Krakow, Poland \\ * Dr hab. inż. Kazimierz Januszek prof. UR, rljanusz@cyf-kr.edu.pl
}

Received: June 27, 2019

Accepted: February 6, 2020

Associated editor: B. Glina

\section{Keywords}

Forest soils

Magnesium deficit

Spruce stands

Sudety mountains

\begin{abstract}
The process of spruce monoculture disintegration has been taking place extensively in all elevated mountainous areas in Poland since the 1980s. This process has accelerated up to a dramatic rate in the $21^{\text {st }}$ century. The aim of this study was to investigate the causes of the considerable weakening of spruce stands in the Śnieżnik Massif and propose of application of fertilization. The study was carried out in the Eastern Sudety Mountains in the upper part of the Śnieżnik Massif, Lądek Zdrój Forest District where spruce stands showed symptoms of strong weakness in 2005. Soil and needles samples were collected for basic laboratory analysis. Strongly weakened spruce stands were found on poor Podzols developed from the Śnieżnik gneiss affected by a magnesium deficit. The spruce stands that did not show clear symptoms of weakening were found on Dystric Cambisols developed from mica schist, which were better supplied with magnesium. The study results indicate that the weakening of spruce stands in the Śnieżnik massif is related to the magnesium deficit and soils of strongly weakened stands require fertilization with this element.
\end{abstract}

\section{Introduction}

The process of spruce monoculture disintegration has been occurring over large areas in all elevated mountainous zones in Poland since the 1980s (Modrzyński, 2003; Bruchwald and Dmyterko, 2010). This process has accelerated up to a dramatic rate in the $21^{\text {st }}$ century especially since 2004 . Modrzyński (2003) found that the defoliation of the investigated spruce stands was progressing dramatically based on studies of dynamic defoliation in 80 to 200-year-old spruce stands in the Sudetes and the Carpathian Mountains between 1989 and 1999. According to Grodzki (1998) the vitality reduction of the Norway spruce stands in the Western Sudetes is the effect of hydrothermic conditions, air pollution and damage caused by the larch bud moth larvae. Atmospheric pollution plays a decisive role in forest degradation in the Izerskie Mountains as it destroys the balance in forest ecosystems. Soil properties are the only predisposing factors (Kabała, 1998). Meanwhile, pollution by $\mathrm{SO}_{2}$ and $\mathrm{NO}_{\mathrm{x}}$ have been declining since 1989, while generally forests across Poland have been showing signs of recovery since 1995. Research performed by Zwoliński (2003), as well as by Małek (2010) revealed that the amounts of sulfur and nitrogen were high, while the amounts of magnesium and calcium were too low in the soil and in the needles of spruce growing in the Beskid Śląski mountain area. Between 1986 and 1988, it was determined that the activity of phosphatases in the mor humus horizon under dying-off of spruce stands in the Western Sudetes was lower in comparison with phosphatase activity in mor humus under spruce stands without any symptoms of dying-off in the Tatra Mountains (Januszek, 1992). Although positive trends existed, expressing themselves in the limiting of air pollutants, primarily sulfur, since the 1980s, the effects of pollution in some areas are still very significant (Filipiak and Ufnalski, 2004; Vacek et al., 2013).

The yellowing of tree crowns and significant defoliation of spruce stands in the Śnieżnik Massif attracted the particular attention of the State Forest Administration in Wrocław in 2005. An extraordinary spring inspection of stand condition conducted in the Śnieżnik Massif area revealed that the most weakened spruce stands were found in the "Uroczysko Nad Lejami" area. There were signs of infestation by Argyresthia glabratella, the spruce pest, together with the most yellowed and thinned tree crowns and the largest amounts of dying or dead trees. The aim of this study was to investigate the causes of the considerable weakening of spruce stands in the "Uroczysko Nad Lejami" area in the Śnieżnik Massif. The further aim was also possibly to propose 
applying fertilizer. We tested the following research hypothesis: there is a relationship between the condition of the investigated spruce stands and the fertility of the forest site, specifically the trophic state of the site, and therefore the abundance of nutrients in the soil.

\section{Materials and methods}

\section{1 Śnieżnik Massif physical geography}

The Śnieżnik Massif create a form where the ridges of various lengths and heights are spread from the highest, centrally located point in all directions. The mighty dome of Śnieżnik (1425 m a.s.l.), rising 100-200 $\mathrm{m}$ above the surrounding hills, serves as the central point. All of the Śnieżnik ridges are separated by deep valleys (Kamienica, Kleśnica, Wilczki, Czarna and Morava, the longest) with steep slopes. The Śnieżnik massif has an almost exactly rectangular shape and is a distinct block, significantly raised above the surrounding units (Migon, 1996). Essentially, there are two metamorphic rock formations present in the research area: the Stronie formation and the Gierałtów-Śnieżnik formation. The Stronie formation is primarily composed of mica schist and paragneiss. The Gierałtów-Śnieżnik formation is represented by plagioclase and microcline gneiss rocks, known in the literature as the Śnieżnik gneiss. The Stronie formation is a rock complex of mixed lithology. Its main mass comprises mica schists and paragneiss with lenses composed of quartzite and light-colored quartzite schist, quartzite and graphite schist, limestone and secondarily amphibolite and erlan. The mineralogical contents of mica schist, as well as paragneiss are qualitatively similar, yet quantitatively different. The primary components are quartz and also light and dark mica (Frąckiewicz and Teisseyre, 1977).

\subsection{Soil sampling and analysis}

The research was conducted in the Śnieżnik Massif area in August of 2005. Spruce stand health served as the criterion for study area selection. Six experimental areas were selected (plots 1-6, Fig.1), where spruce stands were strongly weakened, with needle tips clearly yellowed and an average defoliation of $32.5 \%$ (Table 1). The strongly weakened stands (SWS) were situated within 9 divisions covering a total area of 273 ha, located on both sides of a road running on the slope called "Nad Lejami" ("Over the Hollows"). For the purpose of comparison, 6 areas (plots 7-12, Fig. 1) situated within 6 subdivisions of spruce stands that were not weakened or were slightly weakened (LWS), with green tree crowns and minor defoliation, were designated (Table 1). The soil profile were dug manually on each study plot and soil type was determined according to FAO-WRB classification (IUSS Working Group WRB, 2015) and Polish Soil Classification (Kabała et al., 2019). In total, 75 soil samples with disturbed structure were collected. The cumulative soil samples from the Oea, AE and E horizons were collected from 8 holes (dimensions $20 \mathrm{~cm} \times 20 \mathrm{~cm}$ and depth $40 \mathrm{~cm}$ ) within a radius of $5 \mathrm{~m}$ from the soil profile. Additionally, soil samples from B and BC horizons were taken from the soil profile. The soil samples were air-dried and sifted through a sieve with the size $\emptyset=2 \mathrm{~mm}$ in the laboratory. The undisturbed samples were collected by using metal rings of known

Table 1.

Location and characteristics of strongly weakened (SWS) and least weakened (LWS) the spruce stand study areas

\begin{tabular}{|c|c|c|c|c|c|c|c|}
\hline $\begin{array}{l}\dot{0} \\
\stackrel{a}{0} \\
\stackrel{0}{a}\end{array}$ & 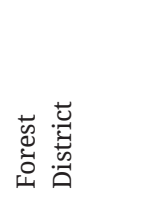 & 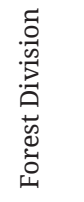 & 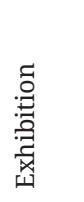 & 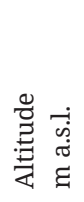 & 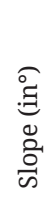 & 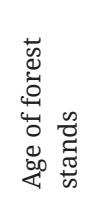 & 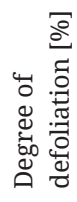 \\
\hline \multicolumn{8}{|c|}{ Strongly weakened stands (SWS) } \\
\hline 1 & Kamienica & $243 a$ & $\mathrm{NE}$ & 995 & 20 & 65 & $11-30$ \\
\hline 2 & & $279 c$ & $\mathrm{~N}$ & 1110 & 31 & 45 & $11-30$ \\
\hline 3 & & $278 \mathrm{a}$ & $\mathrm{E}$ & 1020 & 22 & 99 & $1-30$ \\
\hline 4 & & $240 \mathrm{~b}$ & NNE & 975 & 19 & 104 & $31-60$ \\
\hline 5 & & $277 a$ & E & 1025 & 24 & 74 & $31-60$ \\
\hline \multirow[t]{2}{*}{6} & & $239 c$ & EES & 960 & 22 & 84 & $31-60$ \\
\hline & & & Mean & 1014 & 23 & 79 & 32.5 \\
\hline \multicolumn{8}{|c|}{ Least weakened stands (LWS) } \\
\hline 7 & Kletno & $128 \mathrm{i}$ & EEN & 763 & 27 & 75 & 0 \\
\hline 8 & & $126 \mathrm{~b}$ & E & 759 & 10 & 99 & 0 \\
\hline 9 & & $125 \mathrm{k}$ & EES & 740 & 18 & 55 & 0 \\
\hline 10 & Stronie & $343 a$ & NNW & 1065 & 6 & 89 & $0-11$ \\
\hline 11 & & $342 \mathrm{a}$ & $\mathrm{N}$ & 1080 & 8 & 89 & $0-11$ \\
\hline \multirow[t]{2}{*}{12} & & $344 a$ & sW & 1102 & 4 & 84 & $0-11$ \\
\hline & & & Mean & 918 & 12 & 82 & 2.75 \\
\hline
\end{tabular}

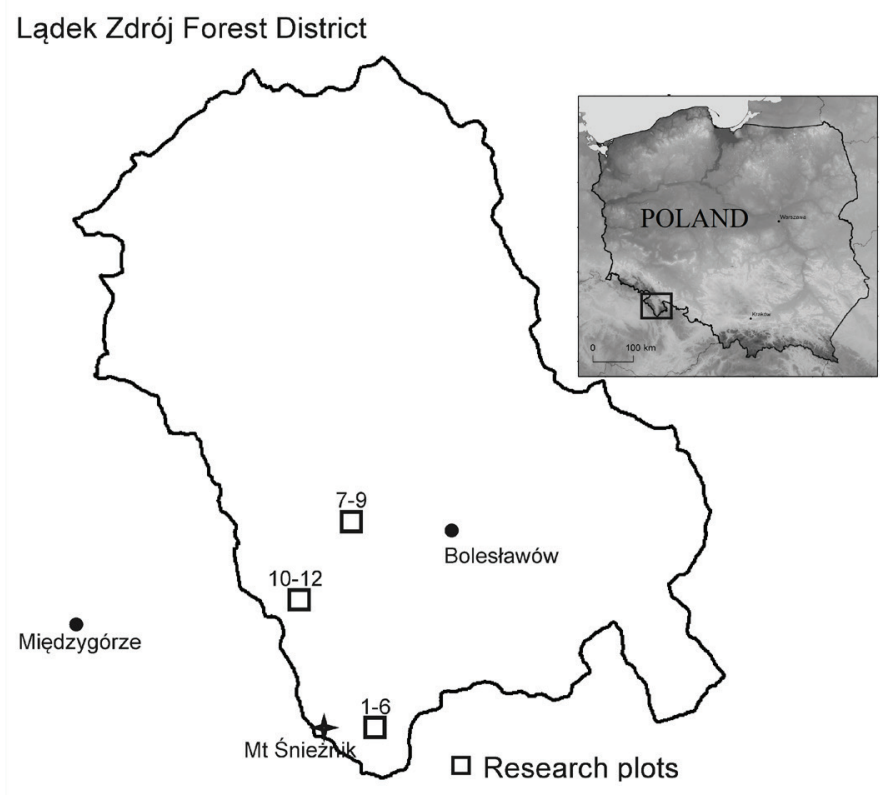

Fig. 1. Localization of research plots (Lądek Zdrój Forest District, southern Poland) 
volumes $\left(250 \mathrm{~cm}^{3}\right)$ from $\mathrm{O}, \mathrm{AE}, \mathrm{E}$ and $\mathrm{B}$ horizons of soil SWS and LWS variant. In total, 24 soil samples with an intact structure were collected for laboratory analysis.

Selected properties were determined using methods widely used in soil science (Ostrowska et al., 1991; Kowalik, 2007). Particle-size distribution was measured using a sieving (sand fraction) and hydrometer method for the determination of the silt and clay fraction (Van Reeuwijk, 2002). The soil pH was analyzed in distilled water and $1 \mathrm{M} \mathrm{KCl}$ using the potentiometric method. The total organic carbon (TOC) content (in mineral horizon) was determined using the Tiurin method and the total nitrogen (TN) content by the Kjeldahl method. Organic matter content in organic horizons was determined by loss on ignition (LOI) after placing the dried samples in a muffle furnace at $550^{\circ} \mathrm{C}$ for 6 hours (the calculation of the organic matter includes a water content of hygroscopic and the average TOC content in the organic substance was taken in the amount of $58 \%$ in the calculation of TOC). Hydrolytic acidity $\left(\mathrm{H}_{h}\right)$ was determined by the Kappen method, base cations content (BC) were determined in $1 \mathrm{M}$ ammonium acetate extract using atomic spectral absorption (ASA) with calculation of the sorption capacity $\left(C E C=B C+\mathrm{H}_{h}\right)$ and base saturation $(\mathrm{BS}=\mathrm{BC} / \mathrm{CEC} * 100)$. Exchangeable acidity $\left(\mathrm{H}_{\mathrm{H}+\mathrm{Al}}\right)$ and exchangeable aluminum $\left(\mathrm{H}_{\mathrm{Al}}\right)$ were determined by the Sokołow method. Available phosphorus were determined by Bray-Kurtz method. The content of $\mathrm{Zn}, \mathrm{Mn}, \mathrm{Cu}$ and $\mathrm{Pb}$ were determined using atomic absorption spectrometer in $1 \mathrm{M} \mathrm{HCl}$ extract. In samples with an undisturbed structure, the capillary water capacity (PWK) was determined by a drying-weight method and in samples of soils with disturbed structure, the maximum hygroscopic water content $(\mathrm{MH})$ in the vacuum chamber over the saturated $\mathrm{K}_{2} \mathrm{SO}_{4}$ solution was determined. Permanent wilting moisture (PWM) was calculated using conversion factor 1.45 in relation to $\mathrm{MH}$ (Kowalik, 2007) and water potential useful retention (RU) was calculated by summing the difference between PWK and PWM for each horizon. In the Oa horizons passed through a sieve ( $\varnothing 2 \mathrm{~mm}$ ) in the state of natural moisture, phosphatase activity (PhA) was determined by Kramer and Erdei (1959) method modified by Tabatabai and Bremner (1969).

\subsection{Needle sampling and analysis}

Needles were collected in November 2005, from 3 cut dominating spruce trees from all plots (Table 1). Two samples of twigs were taken from each tree from the first and second whorls, and from the 7th whorl with the exclusion of the northern side. Needles were separated by hand in the laboratory. The 2005 needles were collected (marked 0.5/1+2) from branches 1 and 2 whorl and two needle samples were obtained (the current 2005 marked 0.5/7 and 2004 - marked 1.5/7) from branches collected from the 7th whorl. After separation from the branches, the needle samples were rinsed with distilled water on a nylon sieve and then dried at $40^{\circ} \mathrm{C}$. The 18 needle samples from SWS and LWS variant were prepared for the study (36 samples in total). The needles were ground using a stainless steel mill. Needle samples were tested for moisture by a drying-weight method at $105^{\circ} \mathrm{C}$. The content of C, N and S was determined using the CNS 2000 Leco elemental analyzer. Ground needles were mineralized with a mixture of concentrated nitric and perchloric acid ( $3: 1)$ (Ostrowska et al., 1991). The content of $\mathrm{K}, \mathrm{Ca}, \mathrm{Mg}, \mathrm{Na}, \mathrm{Cu}, \mathrm{Zn}, \mathrm{Mn}$ and Fe were determined by atomic absorption spectrophotometry using the Varian Spectr AA-20 Analyser. Boron content were determined by the AES ICP method using an atomic plasma spectrometer JY 238. Phosphorus content was determined by the vanadate method using a UV-Vis Varian Carry 300 UV spectrophotometer.

\subsection{Statistical analysis}

All calculations and graphs were prepared using Microsoft Excel and Statistica 10 software (StatSoft Inc., Tulsa, OK, USA). The normality of a variable distribution was checked. The t-test for independent trials (with respect to groups) was performed for variables having a normal distribution. The Mann - Whitney U test and the Kolmogorov - Smirnov test (non-parametric statistics) were performed for variables not having a normal distribution.

\section{Results}

\subsection{Soil properties}

Soils in the SWS areas developed from the Śnieżnik gneiss were classified as Skeletic Albic Podzols (WRB, 2015) and debris podzolic soils (Kabała et al., 2019). Soils in LWS developed from mica schist of the Stronie formation were classified as Skeletic Cambisols (Protospodic) (WRB, 2015) and debris podzolic brown soils (Kabała et al., 2019). The soils developed from the Śnieżnik gneiss found in the remaining 2 LWS areas were classified as Skeletic Dystric Cambisol or Skeletic Albic Podzol (WRB, 2015) and debris acid brown soils or debris podzolic soils (Kabała et al., 2019). The soils in the SWS and LWS areas were categorized as deep (80-130 cm) according to Classification of Forest Soils (2000). The soils in SWS areas were characterized by higher content of

Table 2.

Statistical differences in particle-size distribution in all SWS $(n=23)$ and LWS $(n=25)$ (Kolmogorov-Smirnov test) mineral soil horizons

\begin{tabular}{|c|c|c|c|c|c|c|}
\hline \multirow[b]{3}{*}{$\begin{array}{l}\emptyset \text { fraction } \\
{[\mathrm{mm}]}\end{array}$} & \multicolumn{4}{|c|}{ Spruce stands } & \multirow[b]{3}{*}{$\mathrm{df}$} & \multirow{3}{*}{ 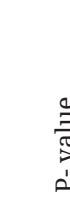 } \\
\hline & \multicolumn{2}{|c|}{ SWS } & \multicolumn{2}{|c|}{ LWS } & & \\
\hline & $\begin{array}{r}\text { Mean } \\
{[\%]}\end{array}$ & $\begin{array}{l}\text { SD } \\
{[\%]}\end{array}$ & $\begin{array}{r}\text { Mean } \\
{[\%]}\end{array}$ & $\begin{array}{r}\text { SD } \\
{[\%]}\end{array}$ & & \\
\hline $1.0-0.5$ & 13.1 & 2.1 & 9.6 & 2.2 & 0.593 & 0.001 \\
\hline $0.5-0.25$ & 13.6 & 2.7 & 9.8 & 2.1 & 0.550 & 0.005 \\
\hline $0.25-0.1$ & 17.3 & 3.6 & 14.6 & 2.4 & 0.532 & 0.005 \\
\hline $0.05-0.02$ & 10.3 & 3.9 & 13.8 & 3.8 & 0.408 & 0.005 \\
\hline $0.02-0.005$ & 7.3 & 2.6 & 12.2 & 3.5 & 0.622 & 0.001 \\
\hline $0.005-0.002$ & 2.2 & 1.3 & 4.4 & 1.5 & 0.529 & 0.005 \\
\hline $2.0-0.05$ & 74.5 & 6.9 & 61.6 & 7.0 & 0.635 & 0.001 \\
\hline $0.05-0.002$ & 19.8 & 6.4 & 30.4 & 6.9 & 0.626 & 0.001 \\
\hline$<0.002$ & 5.7 & 1.7 & 8.0 & 2.7 & 0.495 & 0.010 \\
\hline
\end{tabular}


coarser fractions in comparison to the soils in LWS areas (Table 2) and had higher water permeability calculated based on their particle-size distribution (Waluk, 1973), including rock fragments (> $2 \mathrm{~mm}$ ) or comprising fine-size fraction only (<2 mm): 4.9 times and 2.8 times higher respectively. The soil profile 2 in the SWS area in comparison to the soil profile 12 in the LWS area may store $25 \%$ less water that is potentially useful to plants at 198 and 265 mm respectively (Table 3 ).

The soils of investigated areas were very strong acidic with pH in $\mathrm{H}_{2} \mathrm{O}$ below 4.5 and $\mathrm{pH}$ in $\mathrm{KCl} 3.5$ (Table 4) in the whole profile. The soils of SWS variant in comparison to soils of LWS variant were characterized by higher acidity and lower BS (Table 4). In the $\mathrm{B}$ horizons of soils of SWS areas in comparison to the B horizons of soils of LWS areas $\mathrm{pH}$ in $\mathrm{H}_{2} \mathrm{O}$ was significantly lower (4.04 and 4.37 respectively) (Table 4 ). $\mathrm{KCl}$ was significantly lower in the Oea horizons of SWS soils in comparison to the Oae horizon of LWS soils pH at 2.59 and 2.74 respectively (Table 4). In the B horizons of SWS soils, the exchangeable acidity $\left(\mathrm{H}_{\mathrm{H}+\mathrm{Al}}\right)$ and the concentration of exchangeable aluminum $\left(\mathrm{H}_{\mathrm{Al}}\right)$ were 2 times higher than in B horizons of LWS soils (8.25/4.23 and 8.14/4.14 $\mathrm{cmol} \mathrm{kg}^{-1}$ of soil, respectively). The sum of basic cations was over 2.5 times smaller (2.02/5.28 $\mathrm{cmol} \mathrm{kg}^{-1}$ of soil respectively), while BS was 4 times smaller $(6.2 / 25.2 \%$ respectively (Table 4$)$ ). In horizons $\mathrm{AE}$ of LWS soils in comparison to the AE horizons of SWS soils, the concentration of exchangeable aluminum $\left(\mathrm{H}_{\mathrm{Al}}\right)$ were higher but the values were not statistically significantly differentiated (Table 4). Smaller concentrations of exchangeable Mg were found in soils of SWS areas in comparison to soils of LWS areas. The share of exchangeable $\mathrm{Mg}$ in the mineral horizons of SWS and LWS soils were $1.41 \%$ and $2.15 \%$ respectively. Significantly higher concentrations of available phosphorus were found in the mineral horizons of SWS soils than in LWS soils, with average values of 44.7 and $27.1 \mathrm{mg} \mathrm{kg}^{-1}$ respectively (Table 4). A smaller share of exchangeable forms of magnesium and potassium and a greater share of calcium and sodium were found in the absorbing complex of soils of SWS areas in comparison to soils of LWS areas. The soils of SWS areas, in comparison to the soils of LWS areas, were characterized by higher values of the ratio of exchangeable forms of Ca:Mg at the equivalence point, with significant differences in the mineral horizons altogether at 5.63 and 4.16 respectively. It was found that the concentrations of $\mathrm{Mn}, \mathrm{Zn}$ and $\mathrm{Cu}$, determined in a $1 \mathrm{M} \mathrm{HCl}$ solution in SWS soil horizons, were significantly lower than in LWS soil horizons. No significant differences in the activity of phosphatase (PhA) in the Oa horizons were found, which would make a distinction between the researched SWS and LWS soil groups (Table 4).

\subsection{Concentrations of macroelements and some trace elements in needles}

The higher concentrations of N, P, K, S, Na and Cu were found in the needles of SWS variant in comparison to needles of LWS variant. Lower concentrations of $\mathrm{Mg}$, $\mathrm{Mn}$ and $\mathrm{Zn}$ were found in SWS than in LWS needles (Table 5). The concentrations of $\mathrm{Mg}$ in older needles (1.5/7) were significantly correlated with the soil properties of the B horizon and to a lesser extent with soil properties of AE and Oae horizons. However, no correlation was found with soil properties of $\mathrm{BC}$ horizons. The concentrations of $\mathrm{Mg}$ in the needles $1.5 / 7$ were significantly positively correlated with such properties in the $\mathrm{B}$ horizons as $\mathrm{pH}$ in $\mathrm{H}_{2} \mathrm{O}(\mathrm{r}=0.97$; Fig. 2a) and the degree of base saturation ( $r=0.98$; Fig. $2 b$ ). The concentrations of

Table 3.

The bulk density and water capacity of SWS (plot No. 2, division 279c) and LWS (plot No. 12, division 344a) soils

\begin{tabular}{|c|c|c|c|c|c|c|c|c|}
\hline \multirow[b]{2}{*}{$\begin{array}{l}\text { Plot } \\
\text { no. }\end{array}$} & \multirow{2}{*}{$\begin{array}{l}\text { Soil } \\
\text { depth } \\
\text { [cm] }\end{array}$} & \multirow[b]{2}{*}{$\begin{array}{l}\text { Horizon } \\
{\left[\mathrm{Mg} \mathrm{m}^{-3}\right]}\end{array}$} & \multirow{2}{*}{$\begin{array}{l}\text { Bulk } \\
\text { density } \\
{\left[\mathrm{Mg} \mathrm{m}^{-3}\right]}\end{array}$} & \multirow{2}{*}{$\begin{array}{l}\text { Soil } \\
\text { moisture } \\
{\left[\mathrm{Mg} \mathrm{m}^{-3}\right]}\end{array}$} & \multicolumn{3}{|c|}{ Water capacity } & \multirow{2}{*}{$\begin{array}{r}\text { Useful water } \\
\text { in horizon } \\
\text { RU [g dm-2] }\end{array}$} \\
\hline & & & & & $\begin{array}{l}\text { PWK } \\
{\left[\mathrm{kg} \mathrm{kg}^{-1}\right]}\end{array}$ & $\begin{array}{l}\mathrm{MH} \\
{\left[\mathrm{kg} \mathrm{kg}^{-1}\right]}\end{array}$ & $\begin{array}{l}\text { PWM } \\
{\left[\mathrm{kg} \mathrm{kg}^{-1}\right]}\end{array}$ & \\
\hline \multicolumn{9}{|l|}{ SWS } \\
\hline \multirow{6}{*}{2} & $0-4$ & Oie & 0.12 & 3.014 & 5.040 & 0.349 & 0.506 & 217 \\
\hline & $4-9$ & $\mathrm{Oa}$ & 0.20 & 2.502 & 3.535 & 0.187 & 0.271 & 326 \\
\hline & $9-25$ & AEs & 0.72 & 0.569 & 0.855 & 0.068 & 0.099 & 348 \\
\hline & $25-33$ & Bhs & 0.55 & 0.768 & 1.179 & 0.112 & 0.162 & 179 \\
\hline & $33-69$ & Bs & 0.87 & 0.542 & 0.685 & 0.099 & 0.144 & 678 \\
\hline & $69-90$ & $\mathrm{BC}$ & 0.87 & 0.542 & 0.685 & 0.032 & 0.046 & 233 \\
\hline & & & & & \multicolumn{3}{|c|}{ Total $\mathrm{H}_{2} \mathrm{O}$ in profile $\left[\mathrm{g} \mathrm{dm}^{-2}\right.$ ] } & 1982 \\
\hline \multicolumn{9}{|l|}{ LWS } \\
\hline & $0-4$ & Oie & 0.14 & 2.876 & 4.985 & 0.329 & 0.477 & 251 \\
\hline & $4-9$ & $\mathrm{Oa}$ & 0.21 & 2.788 & 3.799 & 0.263 & 0.381 & 359 \\
\hline \multirow[t]{4}{*}{12} & $9-26$ & AEs & 0.90 & 0.521 & 0.678 & 0.074 & 0.107 & 538 \\
\hline & $26-67$ & Bwg & 1.02 & 0.464 & 0.543 & 0.049 & 0.071 & 1086 \\
\hline & $67-95$ & $\mathrm{BwCg}$ & 1.02 & 0.464 & 0.543 & 0.038 & 0.055 & 418 \\
\hline & & & & & \multicolumn{3}{|c|}{ Total $\mathrm{H}_{2} \mathrm{O}$ in profile [ $\mathrm{g} \mathrm{dm}^{-2}$ ] } & 2652 \\
\hline
\end{tabular}

PWK - capillary water capacity; MH - maximal higroscopic; PWM - permanent wilting moisture;

$\mathrm{RU}$ - potential useful water retention 
Table 4.

Mean values and standard deviations of some properties of strongly (SWS) and least weakened (LWS) spruce stand investigated soils

\begin{tabular}{|c|c|c|c|c|c|c|c|c|c|c|c|}
\hline \multirow[b]{2}{*}{ Properties } & \multirow[b]{2}{*}{ Horizons } & \multicolumn{2}{|l|}{ sWs } & \multicolumn{2}{|l|}{ LWS } & \multirow[b]{2}{*}{ Properties } & \multirow[b]{2}{*}{ Horizons } & \multicolumn{2}{|c|}{ SWS } & \multicolumn{2}{|c|}{ LWS } \\
\hline & & Mean & SD & Mean & SD & & & Mean & SD & Mean & SD \\
\hline \multirow[t]{3}{*}{$\mathrm{pH}$ in $\mathrm{H}_{2} \mathrm{O}$} & Oea & 3.58 & 0.21 & 3.71 & 0.21 & \multirow[t]{3}{*}{$\mathrm{pH}$ in $\mathrm{KCl}$} & Oea & $2.59^{\mathrm{a}}$ & 0.08 & 2.74 & 0.17 \\
\hline & $\mathrm{AE}$ & 3.74 & 0.09 & 3.81 & 0.22 & & $\mathrm{AE}$ & 2.79 & 0.10 & 2.97 & 0.22 \\
\hline & B & $4.04^{\mathrm{a}}$ & 0.24 & 4.37 & 0.28 & & B & 3.35 & 0.27 & 3.74 & 0.39 \\
\hline \multirow{3}{*}{$\begin{array}{l}\text { TOC } \\
{\left[\mathrm{g} \mathrm{kg}^{-1}\right]}\end{array}$} & Oea & 354.6 & 111.3 & 434.7 & 76.8 & \multirow{3}{*}{$\begin{array}{l}\mathrm{H}_{\mathrm{H}+\mathrm{Al}} \\
{\left[\mathrm{cmol}(+) \mathrm{kg}^{-1}\right]}\end{array}$} & Oea & 9.29 & 1.55 & 9.15 & 3.20 \\
\hline & $\mathrm{AE}$ & 31.0 & 29.3 & 41.2 & 22.6 & & $\mathrm{AE}$ & 5.67 & 2.05 & 7.40 & 2.02 \\
\hline & B & 49.5 & 19.4 & 30.7 & 08.8 & & $\mathrm{~B}$ & $8.25^{\mathrm{a}}$ & 2.68 & 4.23 & 3.06 \\
\hline \multirow[t]{3}{*}{$\mathrm{C}: \mathrm{N}$} & Oea & 25.3 & 2.6 & 26.8 & 3.9 & \multirow{3}{*}{$\begin{array}{l}\mathrm{H}_{\mathrm{Al}} \\
{\left[\mathrm{cmol}(+) \mathrm{kg}^{-1}\right]}\end{array}$} & Oea & 8.01 & 2.03 & 7.17 & 3.46 \\
\hline & $\mathrm{AE}$ & 17.8 & 1.1 & 18.3 & 1.9 & & $\mathrm{AE}$ & 5.49 & 2.04 & 7.17 & 2.08 \\
\hline & B & 21.4 & 3.6 & 17.8 & 2.1 & & $\mathrm{~B}$ & $8.14^{\mathrm{a}}$ & 2.72 & 4.14 & 3.02 \\
\hline \multirow{3}{*}{$\begin{array}{l}\mathrm{Ca}^{2+} \\
{\left[\mathrm{mg} \mathrm{kg}^{-1}\right]}\end{array}$} & Oea & 678 & 392 & 938 & 588 & \multirow{3}{*}{$\begin{array}{l}\text { BC } \\
{\left[\mathrm{cmol}^{(+)} \mathrm{kg}^{-1}\right]}\end{array}$} & Oea & 4.62 & 2.37 & 6.46 & 3.41 \\
\hline & $\mathrm{AE}$ & 64.5 & 12.1 & 64.5 & 21.5 & & $\mathrm{AE}$ & 0.53 & 0.15 & 0.55 & 0.15 \\
\hline & B & 78.1 & 24.9 & 58.6 & 29.7 & & B & 0.53 & 0.15 & 0.43 & 0.18 \\
\hline \multirow{3}{*}{$\begin{array}{l}\mathrm{Mg}^{2+} \\
{\left[\mathrm{mg} \mathrm{kg}^{-1}\right]}\end{array}$} & Oea & $83.8^{\mathrm{b}}$ & 36.9 & 142.5 & 51.7 & \multirow{3}{*}{$\begin{array}{l}\text { CEC } \\
{\left[\mathrm{cmol}^{(+)} \mathrm{kg}^{-1}\right]}\end{array}$} & Oea & 13.9 & 1.74 & 15.6 & 1.68 \\
\hline & $\mathrm{AE}$ & $9.4^{\mathrm{a}}$ & 4.4 & 15.8 & 6.3 & & $\mathrm{AE}$ & 6.20 & 2.13 & 7.95 & 2.11 \\
\hline & B & 8.8 & 2.1 & 9.6 & 3.0 & & $\mathrm{~B}$ & $8.80^{\mathrm{a}}$ & 2.68 & 4.66 & 3.08 \\
\hline \multirow{3}{*}{$\begin{array}{l}\mathrm{Na}^{+} \\
{\left[\mathrm{mg} \mathrm{kg}^{-1}\right]}\end{array}$} & Oea & 13.6 & 2.4 & 13.0 & 3.1 & \multirow[t]{3}{*}{ BS [\%] } & Oea & 32.2 & 14.0 & 41.0 & 20.1 \\
\hline & $\mathrm{AE}$ & 5.2 & 2.6 & 3.8 & 0.9 & & $\mathrm{AE}$ & 9.1 & 3.3 & 7.0 & 1.5 \\
\hline & B & 6.9 & 2.6 & 4.4 & 1.8 & & B & 6.7 & 2.7 & 11.4 & 4.7 \\
\hline $\mathrm{K}^{+}$ & Oea & 191.7 & 70.9 & 215.3 & 7.0 & Total N & Oea & 13.8 & 3.0 & 16.3 & 2.8 \\
\hline$\left[\mathrm{mg} \mathrm{kg}^{-1}\right]$ & $\mathrm{AE}$ & 34.0 & 39.4 & 32.9 & 18.1 & [\%] & $\mathrm{AE}$ & 1.7 & 1.6 & 2.3 & 1.2 \\
\hline & B & 19.2 & 07.3 & 17.7 & 5.9 & & $\mathrm{~B}$ & 2.4 & 0.9 & 1.9 & 0.5 \\
\hline Avail. P & Oea & 21.8 & 5.27 & 22.0 & 8.20 & Exch. & Oea & 0.4 & 0.1 & 0.4 & 0.1 \\
\hline [mg kg-1] & $\mathrm{AE}$ & 20.1 & 13.4 & 27.2 & 23.8 & $\mathrm{Na}$ in CEC & $\mathrm{AE}$ & $0.5^{\mathrm{a}}$ & 0.4 & 0.2 & 0.1 \\
\hline & B & 60.8 & 35.1 & 25.7 & 28.6 & {$[\%]$} & B & 0.4 & 0.1 & 0.5 & 0.3 \\
\hline Exch. & Oea & 23.4 & 11.8 & 29.8 & 17.6 & Exch. Mg in & Oea & $4.9^{\mathrm{b}}$ & 1.7 & 7.4 & 2.4 \\
\hline Ca in CEC [\%] & $\mathrm{AE}$ & 5.9 & 2.7 & 4.2 & 1.5 & CEC $[\%]$ & $\mathrm{AE}$ & 1.4 & 0.5 & 1.6 & 0.4 \\
\hline & B & 4.9 & 2.4 & 7.2 & 3.9 & & B & $0.9^{\mathrm{a}}$ & 0.3 & 1.8 & 0.6 \\
\hline Exch. & Oea & 3.5 & 1.1 & 3.5 & 0.9 & Exch. & Oea & 58.91 & 17.92 & 46.49 & 22.67 \\
\hline $\mathrm{K}$ in CEC & $\mathrm{AE}$ & 1.3 & 0.9 & 1.0 & 0.4 & $\mathrm{Al}$ in $\mathrm{CEC}[\%]$ & $\mathrm{AE}$ & 88.03 & 3.78 & 89.66 & 3.31 \\
\hline [\%] & B & 0.6 & 0.1 & 1.2 & 0.9 & & $\mathrm{~B}$ & 91.87 & 3.21 & 87.41 & 5.65 \\
\hline Exch. & Oea & 8.8 & 4.3 & 12.5 & 4.4 & $\left(\mathrm{Ca}^{2+}\right):\left(\mathrm{K}^{+}\right)$ & Oea & 6.9 & 3.6 & 8.4 & 4.1 \\
\hline $\mathrm{H}$ in $\mathrm{CEC}$ & $\mathrm{AE}$ & 2.9 & 1.4 & 3.3 & 3.1 & & $\mathrm{AE}$ & 6.9 & 3.5 & 5.9 & 4.7 \\
\hline [\%] & B & 1.5 & 1.7 & 2.0 & 0.5 & & B & 9.9 & 4.9 & 7.1 & 4.4 \\
\hline $\mathrm{Zn}$ & Oea & 19.3 & 7.2 & 26.1 & 11.1 & $\left(\mathrm{Ca}^{2+}+\mathrm{Mg}^{2+}+\mathrm{K}^{+}\right)$ & Oea & 0.7 & 0.6 & 1.1 & 0.8 \\
\hline$\left[\mathrm{mg} \mathrm{kg}^{-1}\right]$ & $\mathrm{AE}$ & 2.3 & 1.8 & 3.5 & 2.7 & $:\left(\mathrm{Al}^{3+}\right)$ & $\mathrm{AE}$ & 0.1 & 0.1 & 0.1 & 0.1 \\
\hline & B & 2.8 & 0.7 & 7.8 & 7.0 & & B & 0.1 & 0.1 & 0.1 & 0.1 \\
\hline & Oea & $10.9^{\mathrm{a}}$ & 5.2 & 289 & 395 & $\left(\mathrm{Ca}^{2+}\right):\left(\mathrm{Al}^{3+}\right)$ & Oea & 0.5 & 0.4 & 1.3 & 1.7 \\
\hline$\left[\mathrm{mg} \mathrm{kg}^{-1}\right]$ & $\mathrm{AE}$ & $1.93^{b}$ & 0.9 & 129 & 175 & & $\mathrm{AE}$ & 0.1 & 0.1 & 0.1 & 0.1 \\
\hline & B & 35.8 & 44.7 & 388 & 439 & & B & 0.1 & 0.1 & 0.1 & 0.1 \\
\hline $\mathrm{Pb}$ & Oea & 106 & 28.8 & 129 & 67.3 & $\mathrm{Ca}^{2+}: \mathrm{Mg}^{2+}$ & Oea & 4.7 & 1.6 & 3.8 & 1.4 \\
\hline [mg kg-1] & $\mathrm{AE}$ & 22.2 & 20.0 & 33.1 & 22.2 & & $\mathrm{AE}$ & 4.5 & 1.9 & 3.2 & 1.7 \\
\hline & B & 49.5 & 45.6 & 19.3 & 13.6 & & B & 5.7 & 1.7 & 4.0 & 2.2 \\
\hline $\mathrm{Cu}$ & Oea & 8.2 & 0.01 & 15.4 & 7.4 & PhA & $\mathrm{Oa}$ & 35.9 & 9.7 & 36.0 & 12.2 \\
\hline$\left[\mathrm{mg} \mathrm{kg}^{-1}\right]$ & $\mathrm{AE}$ & $0.8^{\mathrm{a}}$ & 0.3 & 2.1 & 0.5 & & & & & & \\
\hline & B & 2.4 & 0.6 & 4.3 & 2.5 & & & & & & \\
\hline
\end{tabular}

n.d.: not determined; Exch. - Exchangeable; Lower case letters in upper indices mean significantly different properties at the level of probability: ${ }^{\text {a }} 0.05 \geq a>0.01$; $^{\mathrm{b}} 0.01 \geq \alpha>0.001$ and $^{\mathrm{c}} \leq 0.001$; PhA phosphatase activity [mg of phenol $5 \mathrm{~g}$ of soil ${ }^{-1} 2$ hour $^{-1}$ ]. 


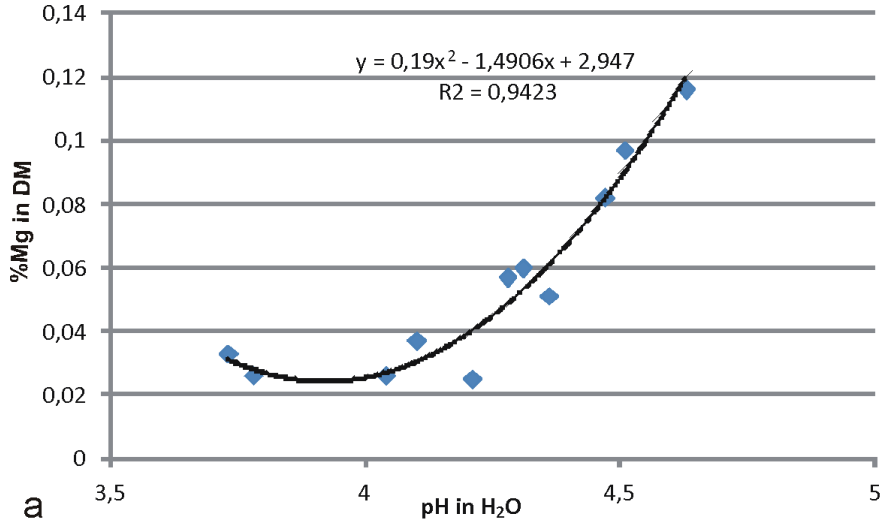

Fig. 2. Relationship between $\mathrm{pH}$ in $\mathrm{H}_{2} \mathrm{O}$ values (a) and the base saturation (Kappen method) (b) in the B horizons of the studied soils and needle magnesium concentration $1.5 / 7$

$\mathrm{Mg}$ in younger needles (0.5/7) were correlated to a lesser extent with the soil properties of the B horizon.

\section{Discussion}

\subsection{Assessment of soil properties under strongly (SWS) and least weakened (LWS) spruce stands in the Śnieżnik Massif}

Soils of the SWS variant compared with the soils of LWS drain rainwater faster and have a smaller water capacity, therefore in the event of a shortage of rainfall, spruce stands growing in soils of this kind may experience a water shortage earlier. In the Izerskie Mountains (Western Sudetes Mts.), Kabała (1998), more dead trees were noted on surfaces with shallow and stony soils than on surfaces with greater depths of soils. According to Ende and Evers (1997), in the Thuringian Forest an extreme deficit of $\mathrm{Mg}$ in older needles $(0.03 \% \mathrm{Mg})$ was detected in areas where soil $\mathrm{pH}$ in $\mathrm{KCl}$ in the Oa horizon was 2.7 while a good supply $(0.09 \% \mathrm{Mg})$ was detected in areas where soil $\mathrm{pH}$ in $\mathrm{KCl}$ in the $\mathrm{Oa}$ horizon was 3.2. The average concentrations of exchangeable $\mathrm{Mg}$ in the first mineral horizons (AE) of SWS soils in the Śnieżnik Massif were below $10 \mathrm{mg} \mathrm{kg}^{-1}$, which was less than $50 \%$ of the suggested threshold value $\left(24.3 \mathrm{mg} \mathrm{kg}^{-1}\right)$ below which the risk of magnesium deficit sharply increases (Ende and Evers, 1997). Mengel and Kirkby (1983) believe there is a need for soil fertilization with magnesium when its share in the sorption complex is smaller than $6 \%$. In the mineral horizons of SWS and LWS soils, the share of exchangeable $\mathrm{Mg}$ were $1.41 \%$ and $2.15 \%$ respectively. The investigated soils under both groups of tree stands showed that they were poor in exchangeable $\mathrm{K}$ though concentration diversity were not statistically significant. The investigated soils are abundant in available P and, according to Nowosielski (1968), do not require phosphorus fertilization even for the cultivation of plants with high requirements. The obtained results ( $\mathrm{pH}$ values $\mathrm{TN}$ content, $\mathrm{C} / \mathrm{N}$ ratio and exchangeable $\mathrm{Mg}$ content) in the SWS soils are similar to those reported for soils of decay spruce forest in the Izerskie Mountains - Western Sudetes Mts. (Kabała, 1998).

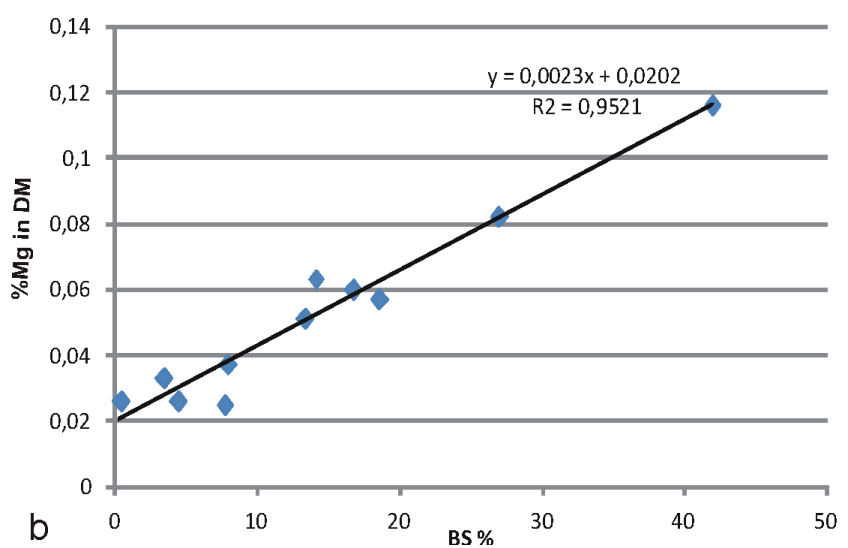

Vavřiček et al. (2005) noted a higher values of $\mathrm{pH}$ in $\mathrm{KCl}$ (in Oea, E and B horizons 2.79-2.84; $2.89-3.00$ and 3.50-3.70 respectively), lower concentration of total nitrogen, higher $\mathrm{C}: \mathrm{N}$ ratio in Oea horizons, higher values of Mg content (but by Mehlich Method) in mineral horizons and clearly lower concentration of $\mathrm{Mg}$ in 1-year and 2-year needles in declining Norway spruce forest in the Hanušovická highland mountain zone (Czech Republic) compare to soils and needles of SWS in Śnieżnik Massif.

\subsection{Nutrition status of strongly weakened (SWS) and least weakened (LWS) spruce stands}

The average $\mathrm{N}$ concentration values in the needles in both SWS as well as the LWS variant may be considered as slightly higher than sufficient according to Zottl (1990), as a deficit level (1.2-1.5\%) according to Brække and Salih (2002), and by Mellert and Göttlein (2012) as the low end of the normal range (1.4-1.5\%). The smaller $\mathrm{N}$ concentration in the older (1.5/7) compared to the younger needles (0.5/7) did not indicate an excess of needle $\mathrm{N}$ in spruce stands in the Śnieżnik Massif in 2005 (Cape et al., 1990). The average values of $\mathrm{P}$ content in all the researched needles may be considered sufficient (Zottl, 1990; Mellert and Göttlein, 2012), or slightly exceeding, according to Brække and Salih (2002), the critical $10 \%$ content of $\mathrm{P}$ with respect to $\mathrm{N}$. The average content of $\mathrm{K}$ in the SWS needles $0.5 / 7$ was in the middle of the normal range (Mellert and Göttlein, 2012). Higher concentrations of K in SWS needles than in LWS needles rather indicated there were imbalances in the ionic equilibrium (Cape et al., 1990), in this case due to a clear Mg deficit in SWS needles. A lower concentration of $\mathrm{K}$ in the older (1.5/7) than younger needles (0.5/7) confirm a nutrient imbalance in the researched stands because the concentration of K increases with the age of needles in balanced forest ecosystems (Cape et al., 1990) although the differences were statistically not significant. The concentration of $\mathrm{Ca}$ in the needles $1.5 / 7$ was below the accepted threshold value of $0.3 \% \mathrm{Ca}$ dry matter, which would qualify these stands as at risk of decline (Cape et al., 1990). According to Brække and Salih (2002), the concentration of $\mathrm{Ca}$ in the needles $0.5 / 7$ was much higher than the level of optimum 
Table 5 .

The content of macro- and microelements in the needles of 0.5 annual proceeds from the branch whorl 1 and 2 , and 0.5 and 1.5 annual proceeds from the branches of the seventh whorl, the average dominant trees of strong (SWS) and least (LWS) weakened spruce stands

\begin{tabular}{|c|c|c|c|c|c|c|c|c|c|c|c|c|c|c|}
\hline \multirow{2}{*}{$\begin{array}{l}\text { Spruce } \\
\text { stands }\end{array}$} & \multirow[b]{2}{*}{ Values } & $\mathrm{C}$ & $\mathrm{N}$ & $\mathrm{P}$ & $\mathrm{K}$ & $\mathrm{Ca}$ & $\mathrm{Mg}$ & $S$ & $\mathrm{Na}$ & $\mathrm{Mn}$ & $\mathrm{Zn}$ & $\mathrm{Cu}$ & $\mathrm{Fe}$ & B \\
\hline & & \multicolumn{7}{|c|}{$\%$ dry matter } & \multicolumn{6}{|c|}{ mg kg-1 dry matter } \\
\hline \multicolumn{15}{|c|}{ Needles of 0.5 year old of 1 and 2 whorl $(0.5 / 1+2$} \\
\hline \multirow[t]{2}{*}{ SWS } & MeanSD & 53.3 & $1.63 a$ & 0.198 & 0.648 & 0.239 & 0.092 & $0.106 a$ & 17.0 & 322 & 21.6 & 3.07 & 48.5 & 21.7 \\
\hline & & 0.7 & 0.051 & 0.018 & 0.147 & 0.067 & 0.023 & 0.006 & 2.5 & 119.8 & 4.69 & 0.18 & 5.6 & 2.46 \\
\hline \multirow[t]{2}{*}{ LWS } & MeanSD & 52.8 & $1.45 \mathrm{a}$ & 0.164 & 0.557 & 0.205 & 0.119 & $0.096 \mathrm{a}$ & 15.2 & 468 & 23.1 & 3.08 & 51.4 & 22.4 \\
\hline & & 0.6 & 0.119 & 0.027 & 0.127 & 0.052 & 0.022 & 0.010 & 3.5 & 247.8 & 6.15 & 0.29 & 89.0 & 1.53 \\
\hline \multicolumn{15}{|c|}{ Needles 0.5 year old of 7 whorl $(0.5 / 7)$} \\
\hline \multirow[t]{2}{*}{ SWS } & MeanSD & 53.0 & 1.49 & $0.182 \mathrm{~A}$ & $0.636 \mathrm{a}$ & 0.182 & $0.053 \mathrm{bA}$ & $0.095 \mathrm{~A}$ & 18.0 & 216 & $17.4 \mathrm{~A}$ & $2.88 \mathrm{~A}$ & $55.8 \mathrm{~B}$ & 15.9 \\
\hline & & 0.7 & 0.088 & 0.016 & 0.113 & 0.023 & 0.008 & 0.006 & 3.4 & 53.1 & 3.48 & 0.28 & 6.3 & 1.90 \\
\hline \multirow[t]{2}{*}{ LWS } & MeanSD & 52.6 & 1.43 & 0.156 & $0.445 a$ & 0.225 & $0.109 \mathrm{~b}$ & 0.091 & $14.5 \mathrm{~A}$ & 495 & 23.4 & 2.73 & 49.7B & 15.5 \\
\hline & & 0.6 & 0.089 & 0.303 & 0.096 & 0.069 & 0.025 & 0.007 & 1.9 & 410.1 & 7.01 & 0.13 & 4.9 & 2.94 \\
\hline \multicolumn{15}{|c|}{ Needles of 1.5 year old of 7 whorl (1.5/7) } \\
\hline \multirow[t]{2}{*}{ SWS } & MeanSD & 53.2 & 1.45 & $0.151 \mathrm{~A}$ & 0.565 & 0.207 & $0.033 \mathrm{bA}$ & $0.102 \mathrm{~A}$ & 22.5 & 196 & $12.9 \mathrm{aA}$ & $3.27 \mathrm{aA}$ & 75.1B & 13.7 \\
\hline & & 0.7 & 0.096 & 0.013 & 0.088 & 0.029 & 0.010 & 0.004 & 4.2 & 41.8 & 1.36 & 0.23 & 7.8 & 1.91 \\
\hline \multirow[t]{2}{*}{ LWS } & MeanSD & 52.8 & 1.35 & 0.133 & 0.481 & 0.271 & $0.079 \mathrm{~b}$ & 0.097 & $21.7 \mathrm{~A}$ & 582 & $21.9 \mathrm{a}$ & $2.69 a$ & $64.1 \mathrm{~B}$ & 14.4 \\
\hline & & 0.5 & 0.087 & 0.020 & 0.089 & 0.105 & 0.024 & 0.007 & 6.7 & 493.7 & 10.51 & 0.35 & 6.5 & 3.59 \\
\hline \multicolumn{15}{|c|}{ All needles together $(\mathrm{N}=18)$} \\
\hline \multirow[t]{2}{*}{ SWS } & MeanSD & 53.2 & 1.52 & $0.177 a$ & $0.617 \mathrm{~b}$ & 0.209 & $0.059 \mathrm{~b}$ & $0.101 \mathrm{a}$ & $21.0 \mathrm{~b}$ & $245 b$ & 17.3 & $3.08 \mathrm{a}$ & 59.8 & 17.1 \\
\hline & & 0.7 & 0.110 & 0.025 & 0.118 & 0.048 & 0.029 & 0.007 & 4.3 & 93.8 & 4.87 & 0.27 & 13.1 & 3.97 \\
\hline \multirow[t]{2}{*}{ LWS } & MeanSD & 52.7 & 1.41 & $0.151 \mathrm{a}$ & $0.506 \mathrm{~b}$ & 0.234 & $0.102 b$ & $0.095 a$ & $17.1 \mathrm{~b}$ & $515 b$ & 22.8 & $2.83 a$ & 55.1 & 17.4 \\
\hline & & 0.6 & 0.103 & 0.028 & 0.104 & 0.079 & 0.028 & 0.008 & 5.4 & 376.4 & 7.65 & 0.31 & 9.3 & 4.52 \\
\hline
\end{tabular}

Mean - mean value from 6 plots; SD - standard deviation; lowercase letters in upper indices represent the differentiated average values between strong (SWS) and light weakened stands (LWS), and bigger case letters between 0,5 and 1,5 - annual old needless respectively at the levels: $\mathrm{a}, \mathrm{A}<0.05$ and $>0.01 ; \mathrm{b}, \mathrm{B} \leq 0.01$ and $\mathrm{c}, \mathrm{C}>0.001$ supply (>0.07\% Ca of dry matter) and it exceeded the critical value (4\%) with respect to $N$, being at least 3 times as high as the critical value. Vavřiček et al. (2005) found the concentration of Ca in 1-year old needles was about $0.14 \%$ in spruce in zero defoliation category. The average concentrations of magnesium in the needles 0.5/7 of SWS indicated a deficit (Mellert and Göttlein, 2012; Cape et al., 1990; Brække and Salih, 2002). The average value of N:Mg ratio in the needles $0.5 / 7$ of SWS (28.5) significantly exceeded the value of the upper threshold (21), and in LWS needles it placed itself in the middle of the normal supply (Mellert and Göttlein, 2012; Ende and Evers, 1997). In the 1.5/7 SWS needles, the average value of $\mathrm{N}: \mathrm{Mg}$ quotient (47.0) significantly exceeded the threshold value (30.0) proposed by Cape et al. (1990), identifying these stands as endangered with dying off. The concentrations of $S$ in the needles $0.5 / 7$ of SWS as well as LWS may be considered normal (Cape et al., 1990). These concentrations do not entitle the respondents to recognize the areas under the direct influence of sulfur emitters. These concentrations are not the kind that would damage the needles. However, a concentration of sulfur in the older needles $(0.102 \%)$, which was higher than in the younger needles (0.095) of SWS, and the difference was statistically significant, would indicate an excess of sulfur (Simončič and Kalan, 1996; Fürst et al., 2003).

The concentrations of trace elements ( $\mathrm{Mn}, \mathrm{Zn}, \mathrm{Cu}, \mathrm{Fe}$ and B) in the needles should be considered as normal. These neither indicate a deficit nor are they toxic (Zottl, 1990; Saarsalmi and Tamminen, 2005). It was shown that foliage nutrient quotients and the differences in the amounts of elements, which emerge between age categories of needles, may be as important to the diagnosis of plant nutrient imbalance and visible symptoms as the absolute values (Cape et al., 1990). The average values of the mass quotients in the needles 1.5/7 of SWS exceeded the threshold values of the $\mathrm{N}: \mathrm{Mg}, \mathrm{S}: \mathrm{Mg}, \mathrm{K}: \mathrm{Mg}(>30,>3$ and $>15$ respectively), proposed for the spruce stands in Europe (Cape et al., 1990). Also, the values of the equivalence quotient of $\mathrm{Ca}: \mathrm{Mg}$ (in all the researched needles) were significantly larger in SWS needles than in LWS needles. This would indicate that the strongly weakened stands (SWS) in the Śnieżnik Massif in 2005 were threatened with dying off due to $\mathrm{Mg}$ deficits.

The values of the $\mathrm{C}: \mathrm{N}$ ratio in SWS in comparison to LWS needles were significantly smaller in the needles $0.5 / 1+2$ and in all needles (Table 6 ). This was due to the differences in $\mathrm{N}$ concentrations being greater than the differences in the TOC (Table 4). It would consequently lead to an $\mathrm{N}$ accumulation occurring to a greater degree in SWS needles than LWS in the Śnieżnik Massif in 2005, due to a magnesium deficit (Marschner, 1995). 


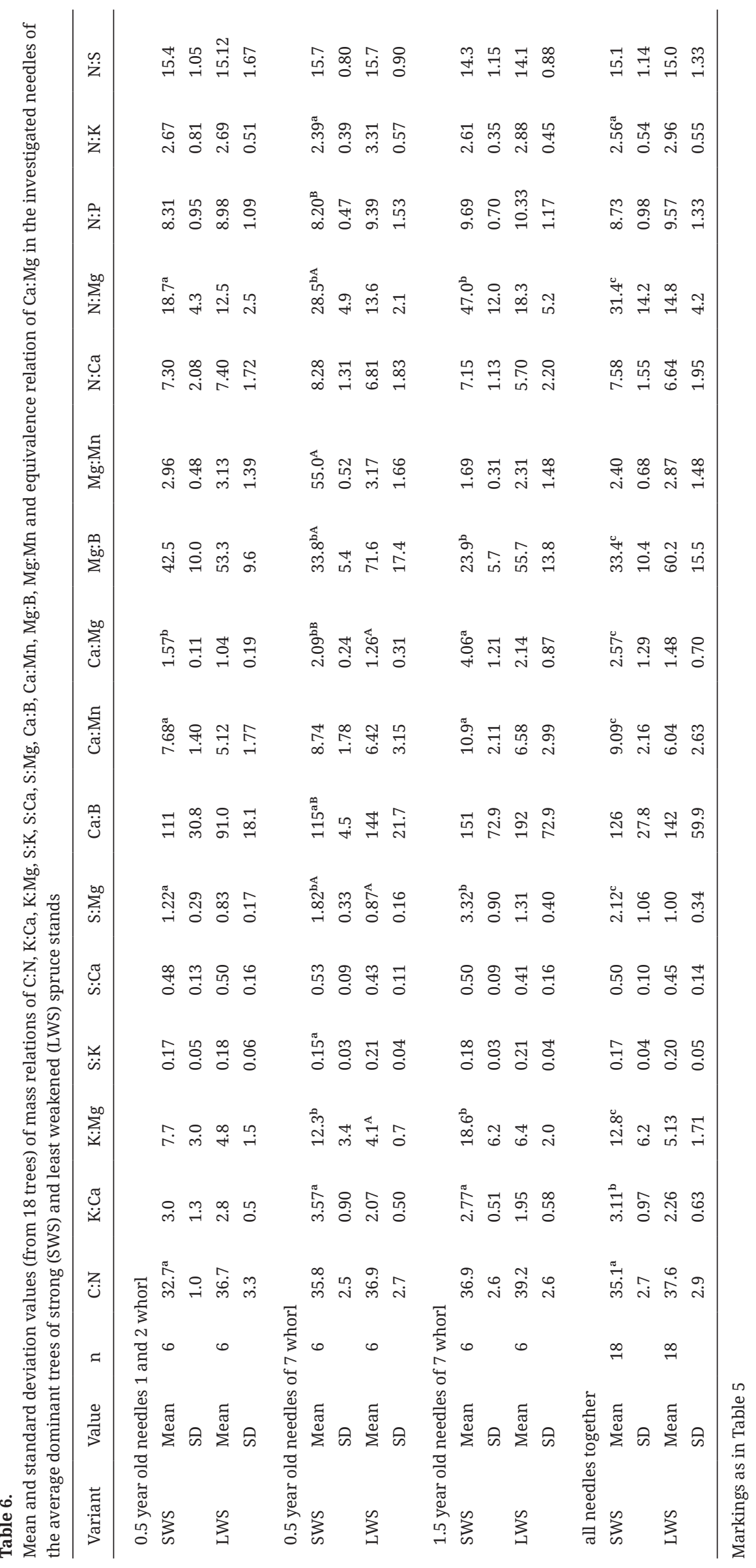




\subsection{Trophic conditions of the spruce stands in the Śnieżnik Massif}

Lack of soil water or its deficit for a longer period of time may occur in all soils and lead to weakening or dying of the stand. Shallow, stony soils with a coarse texture and low retention capacity are particularly vulnerable to stand weakening. Soils of this kind should not be afforested with spruce as it is a species with high water requirements. Therefore, what is the reason for the worse condition of the stands growing in mountainous areas with high rainfall? The concentrations and values of nutrient ratio in soils and needles indicated, without a doubt, that there is a deficit of Mg only (Oren and Schulze, 1989) in the studied soils and SWS needles in the Śnieżnik Massif. The Mg deficit was caused by both the deficit concentration of naturally poor soils as well as the possibly of $\mathrm{Mg}$ exhaustion due to $\mathrm{N}$ oversaturation of the researched habitats. The rate of throughfall $\mathrm{N}$ deposition under the crowns of coniferous trees in the Orlickie Mountains (in the neighborhood of the Śnieżnik Massif) was on average $61.4 \mathrm{~kg}$ $\mathrm{N} \cdot \mathrm{ha}^{-1}$ year $^{-1}$ and the average rate of nitrate nitrogen deposition was an impressive $35.4 \mathrm{~kg} \mathrm{~N} \cdot \mathrm{ha}^{-1}$ year $^{-1}$ between $1994-2000$ (Vottová, 2003). It was the highest measured in Europe and possibly the highest in the world (Gundersen, 1995; Dise et al., 2009). Nitrogen deposition in many parts of Europe considerably exceeds calculated critical loads (Rosén et al., 1992). Most temperate forest ecosystems are traditionally considered as N-limited (Spiecker, 1999). Initial deposits of anthropogenic origin $\mathrm{N}$ lead to an increase in forest productivity (Elfving and Tegnhammar, 1996; Spiecker, 1999). In the long run, constantly high deposits of $\mathrm{N}$ contribute to an increased uptake of the remaining nutrients necessary for plant development, thus intensifying the natural acidification of soil, and drive the nutrients at a minimum down to their deficit levels in the soil (Nihlgård, 1985; Thelin, 2000; Veresoglou et al., 2014; Jonard et al., 2015; Novotnỳ et al., 2018). An increased N level and an imbalance of nutrients increase the susceptibility of trees to attacks by pathogens and sucking insects (Flückiger and Braun, 1999).

A lower concentration of $\mathrm{N}$ observed in the Oea horizons of SWS soils than in Oea horizons of LWS soils may serve as evidence of greater decreases of deposited N in Oea horizons of SWS soils. This is an effect of intensified nitrification, diminished capability of SOM to stabilize nitrogen, steeper slopes, coarser soil texture, greater soil permeability and decreased $\mathrm{N}$ retention kinetics (Castellano et al., 2013), and consequently intensified leaching of basic cations especially magnesium (McNulty et al., 1996). A relatively low concentration of nitrogen in the needles of spruce stands in, both SWS and LWS, may indicate a decreased rate of mineralization of organic matter as an effect of long-lasting, large $\mathrm{N}$ supply in the study area, which is in line with the insights of Rennenberg and Dannenmann (2015). Very good P levels (class 3, according to Stefan et al. (1995)) and deficient Mg in the SWS needles in the Śnieżnik Massif would confirm the hypothesis that if $\mathrm{P}$ is available, some plants with $\mathrm{Mg}$ deficit increase the amount of $\mathrm{P}$ they hold in their organs, most likely in order to compensate for the lack of $\mathrm{Mg}^{2+}$ (Slovik, 1997). The N:P ratio in SWS and LWS stand needles would indicate slight loss of balance between the concentration of $\mathrm{N}$ and $\mathrm{P}$ in the studied stand needles. Veresoglou et al. (2014) shared similar insights. $\mathrm{Mn}^{2+}$ can at least partially substitute for $\mathrm{Mg}^{2+}$ in plants growing on $\mathrm{Mg}^{2+}$ depleted, acidic soils, which can supply $\mathrm{Mn}^{2+}$ (Marschner, 1995; Kaupenjohann, 1997). The exhaustion of Mn available for trees naturally less well supplied with $\mathrm{Mg}$ and $\mathrm{Mn}$ in highly permeable SWS soils under conditions of water deficit (drought) may have occurred sooner than in the less permeable LWS soils that were however prone to retain water and were naturally better supplied with $\mathrm{Mg}$ and Mn, making it impossible to keep using Mn instead of Mg in many physiological processes (Marschner, 1995; Slovik, 1997). There are no grounds to think that the cause for the spruce health condition of in the Śnieżnik Massif was heavy metal contamination, especially given that no differences in the activity of phosphatase were determined in the organic horizons of SWS and LWS soils. The activity of phosphatases is a sensitive indicator of heavy metal soil pollution (Tyler, 1975).

The decision on applied fertilizer selection to revitalize tree-stand soils should be preceded by a detailed examination of habitat conditions including tree-stand nutrient status. Fertilization with magnesite was recommended to improve the health of strongly weakened spruce stands in the Śnieżnik Massif. It was recognized that the studied soils are sufficiently supplied with calcium and there is no need to apply fertilizers containing calcium to weakened spruce stands due to the low demand of coniferous trees for calcium (Małek et al., 2014). A relatively low dose of magnesite was recommended based on spruce stand low magnesium deman and the beneficial effect of low doses of magnesite on soil and plant properties (Małek et al., 2014). In 2006, fertilization with magnesite in the amount of $2000 \mathrm{~kg} \cdot \mathrm{ha}^{-1}$ was carried out and the positive effects of this fertilization for growth of the SWS and soil properties were described (Szydłowska and Socha, 2014; Januszek et al., (in press)). The effects of carried out fertilization proved that the reason for the poor condition of SWS is the soil magnesium deficit in the Śnieżnik Massif.

\section{Conclusions}

Weakness of spruce stands in the Śnieżnik Massif is associated with the fertility of the forest sites. Strongly weakened spruce stands were found on poor Skeletic Albic Podzols, characterized by larger grain content and higher water permeability, with lower water retention capabilities, developed from the Śnieżnik gneiss and affected by a severe magnesium deficit. The spruce stands not showing clear symptoms of weakening were found mostly on Skeletic Dystric Cambisols (Protospodic), characterized by finer texture and higher water retention capabilities, which had developed from mica schist and were better supplied with magnesium.

The concentration of soil magnesium better reflects the concentration of magnesium in two-year needles than in annual needles of the 7 whorl. Among the examined O, AE, B and BC soil horizons, magnesium concentration of in two-year-old spruce needles of the 7 whorl best reflected the B horizon.

The selection of applied fertilizer to revitalize soils under tree stands should be preceded by a detailed examination of forest site conditions and tree stand nutrient status. It is necessary to revitalize soils under spruce stands with special attention to the 
ratio between calcium and magnesium in the soil as well as in the needles, due to the low calcium requirements of coniferous species and plants' passive calcium uptake.

In order to improve the health of strongly weakened spruce stands in the Śnieżnik Massif, a one-time magnesite fertilization of $2000 \mathrm{~kg} \cdot \mathrm{ha}^{-1}$ was recommended.

\section{Acknowledgements}

This research was financed by the The State Forest Administration in Wrocław and by the Ministry of Science and Higher Education of the Republic of Poland. We would like to thank The State Forest Administration in Wrocław for its support in the research project. The Lądek Zdrój Forest District Administration are acknowledged for help in field studies. Bożena Dobroś, Regina Głowacka and Agnieszka Wojciechowicz are acknowledged for their help with chemical analysis.

\section{References}

Brække, F.H., Salih N., 2002. Reliability of foliar analyses of Norway spruce stands in a Nordic gradient. Silva Fennica 36(2), 489-504. https://doi.org/10.14214/sf.540

Bruchwald, A., Dmyterko, E., 2010. Forests of the Silesian and Żywiec Beskids - threats, hope. IBL Sękocin Stary, 88 pp. (in Polish).

Cape, J.N., Freer-Smith, P.H., Paterson, I.S., Parkinson, J.A., Wolfenden, J., 1990. The nutritional status of Picea abies (L.) Karst. Across Europe, and implications for forest decline. Trees 4, 211-224. https://doi. org/10.1007/BF00225318

Castellano, M.J., Lewis, D.B., Kaye, J.P., 2013. Response of soil nitrogen retention to the interactiveeffects of soil texture, hydrology, and organic matter. Journal Geophysics Research Biogeoscience 118, 280-290. https://doi.org/10.1002/jgrg.20015

Dise, N.B., Rothwella, J.J., Gauci, V., van der Salm, C., de Vries, W., 2009 Predicting dissolved inorganic nitrogen leaching in European forests using two independent databases. Science of the Total Environment 407, 1798-1808. https://doi: 10.1016/j.scitotenv.2008.11.003

Elfving, B., Tegnhammar, L., 1996. Trends of tree growth in Swedish for ests 1953+1992: an analysis based on sample trees from the National Forestry Inventory. Scandinavian Journal of Forest Research 11, 26 37. https://doi.org/10.1080/02827589609382909

Ende, H.P., Evers, F.H., 1997. Visual magnesium deficiency symptoms (coniferous, deciduous trees) and threshold values (foliar, soil). [In:] Hüttl, R.F., Schaaf, W., (Eds), Magnesium Deficiency in Forest Ecosystems. Kluwer Academic Publishers, 3-21.

Filipiak, M., Ufnalski, K., 2004. Growth Reaction of European Silver Fir [Abies alba Mill.] Associated with Air Quality Improvement in the Sudeten Mountains. Polish Journal of Environmental Studies 13(3), 267-273.

Flückiger, W., Braun, S., 1999. Nitrogen and its effects on growth, nutrient status and parasite attacks in Beech and Norway spruce. Water Air and Soil Pollution 116, 99-110. https://doi.org/10.1023/A:1005298609109

Frąckiewicz, W., Teisseyre, H., 1977. Provide polish title (Explanations to the detailed geological map of the Sudetes). Międzygórze 1:25 000, Warszawa IGWG (in Polish).

Fürst, A., Smidt, S., Herman, F., 2003. Monitoring the impact of sulphur with the Austrian bioindicator grid. Environmental Pollution 125, 13-19. https://doi.org/10.1016/S0269-7491(03)00091-5

Grodzki, W., 1998. Selected stress symptoms in the Norway spruce stands of the Western Sudety Mountains in the aspect of the effect of the abiotic factors and the larch bud moth Zeiraphera griseana $\mathrm{Hb}$. (Lepidoptera: Totricidae) outbreak. Prace Instytutu Badawczego Leśnictwa Seria A 848, 127-155.

Gundersen, P., 1995. Nitrogen deposition and leaching in European forest - preliminary results from a data compilation. Water Air and Soil Pollution 85, 1179-1184. https://doi.org/10.1007/BF00477141

Instrukcja Ochrony Lasów (Forest Protection Instruction), 2004. CILP. Warszawa, $124 \mathrm{pp}$.

IUSS Working Group WRB (2015) World Reference Base for Soil Resources 2014, Update 2015. International Soil Classification System for Naming Soil and Creating Legends for Soil Maps. World Soil Resources Reports No. 106, Food and Agriculture Organization of the United Nations (FAO), Rome, 190 pp.

Januszek, K., 1992. Enzymatic activity of epihumus horizon of selected spruce soils of the Western Sudetes and Tatra Mountains. Zeszyty Naukowe Uniwersytetu Rolniczego im. Hugona Kołłątaja w Krakowie 269(22), 81-101 (in Polish).

Jonard, M.A. et al., 2015. Tree mineral nutrition is deteriorating in Europe. Global Change Biology 21, 418-430. https://doi.org/10.1111/gcb.12657

Kabała, C., 1998. Properties of soils at the forest decay area in Izerskie Mountains (West Sudety Mts.). Roczniki Gleboznawczce - Soil Science Annual 49(3/4), 119-134.

Kabała, C., et al., 2019. Polish Soil Classification, 6th edition - principles, classification scheme and correlations. Soil Science Annual 70(2), 71-97.

Kaupenjohann, M., 1997. Tree nutrition. [In:] Hüttl, R.F., Schaaf, W. (Eds), Magnesium Deficiency in Forest Ecosystems. Kluwer Academic Publishers, 275-298.

Klasyfikacja Gleb Leśnych Polski (Clasification of Polish Forest Soils), 2000. CILP, Warszawa, 122 pp.

Kowalik, P., 2007. Outline of land physics. Gdansk University of Technology Publisher, Gdańsk, 119 pp.

Kramer, R., Erdei, G., 1959. Primenenie metoda opredeleniâ aktivnosti fosfatazy v agrohimičeskih issledovaniâh (Method for determining phosphatase activity in Czech agricultural soils). Počvoved 9, 99-102.

Małek, S., 2010. Nutrient fluxes in planted Norway spruce stands of different age in Southern Poland. Water Air and Soil Pollution 209, 45-59. https://doi.org/10.1007/s11270-009-0180-z

Małek, S., Januszek, K., Keeton, W.S., Barszcz, J., Kroczek, M., Błońska, E., Wasnic, T., 2014. Preliminary Effects of Fertilization on Ecochemical Soil Condition in Mature Spruce Stands Experiencing Dieback in the Beskid Śląski and Żywiecki Mountains, Poland. Water Air Soil Pollution 225, 1971. https://doi.org/10.1007/s11270-014-1971-4

Marschner, H., 1995. Mineral nutrition of higher plants. Second Edition. Academic Press, $672 \mathrm{pp}$.

McNulty, S.G., Aber, J.D., Newman, S.D., 1996. Nitrogen saturation in a high elevation spruce-fir stand. Forest Ecology and Management 84, 109-121. https://doi.org/10.1016/0378-1127(96)03742-5

Mellert, K.H., Göttlein, A., 2012. Comparison of new foliar nutrient thresholds derived from van den Burg's literature compilation with established central European references. European Journal of Forest Research 131, 1461-1472. https://doi.org/10.1007/s10342-012-0615-8

Mengel, K., Kirby, E. A., 1983. Podstawy żywienia roślin (Basics of plant nutrition). PWRiL, Warszawa, 526 pp. (in Polish)

Migoń, P., 1996. Outline of geomorphological development of the Śnieżnik Massif. [In:] Jahn, A., Kozłowski, S., Pulina, M. (Eds), Śnieżnik Massif. changes in the natural environment. PAE, Wrocław, 35-45 (in Polish).

Modrzyński, J., 2003. Defoliation of older Norway spruce (Picea abies /L/ Karst.) stands in the Polish Sudety and Carpathian mountains. Forest Ecology and Management 181, 289-299. https://doi.org/ 10.1016/ S0378-1127(02)00657-6

Nihlgård, B., 1985. The ammonium hyphothesis: An additional explanatation to the forest dieback in Europe. Ambio 14(1), 2-8.

Novotnỳ, R., Lomskỳ, B., Šrámek, V., 2018. Changes in phosphorus supply in young spruce stands in the Lužické, the Jizerské and the Orlické 
Mts. in the Czech Republic during the 2004-2014 period. European Journal of Forest Research 137(6), 879-894. https://doi.org/10.1007/ s10342-018-1146-8

Nowosielski, O., 1968. Metody oznaczania potrzeb nawożenia (Methods for determining the need for fertilization). PWRiL Warszawa, $310 \mathrm{pp}$. (in Polish).

Oren, R., Schulze, E.D., 1989. Nutritional disharmony and Forest decline: a conceptual model. [In:] Schulze, E.D., Lange, O.L., Oren, R. (Eds), Forest Decline and Air Pollution. Ecological Studies, Springer, Berlin, 425-443.

Ostrowska, A., Gawlinski, S., Szczubiałka, Z., 1991. Metody analizy i oceny właściwości gleb i roślin (Methods of analysis and assessment of soil and plant properties). Environmental Protection Institute, Warszawa, 333 pp. (in Polish).

Procedure for soil analysis 1995. ISRIC, FAO. Technical Paper 9. Ed. L.P. van Reeuwijk. Fifth edition, Wageningen.

Rennenberg, H., Dannemann, M., 2015. Nitrogen Nutrition of Trees in Temperate Forests - The Significance of Nitrogen Availability in the Pedosphere and Atmosphere. Forests 6, 2820-2835. https://doi. org/10.3390/f6082820

Rosén, K., Gundersen, P., Tegnhammar, L., Johansson, M., Frogner, T., 1992. Nitrogen enrichment of nordic forest ecosystems - the concept of critical loads. Ambio 21, 363-368.

Saarsalmi, A., Tamminen, P., 2005. Boron, phosphorus and nitrogen fertilization in Norway spruce stands suffering from growth disturbances. Silva Fennica 39(3), 351-364. https://doi.org/ 10.14214/sf.373

Simončič, P., Kalan, P., 1996. Annual pattern of sulphur content in Spruce needles from heavily and less polluted areas. Phyton (Horn, Austria) 36(3), 81-84.

Slovik, S., 1997. Tree physiology. [In:] Hüttl, R.F., Schaaf, W. (Eds), Magnesium Deficiency in Forest Ecosystems. Kluwer Academic Publishers, 101-214.

Spiecker, H., 1999. Overview of recent growth trends in European forest. Water Air and Soil Pollution 116, 33-46. https://doi. org/10.1023/A:1005205515952

Stefan, K., Fürst, A., Hacker, R., Bartels, U., 1997. Forest foliar condition in Europe. Results of large-scale foliar chemistry surveys. European Commission-United Nations/Economic Commission for Europe, Brussels, $95 \mathrm{pp}$.
Szydłowska, P., Socha, J., 2014. Experimental mineral fertilization as an alternative way to improve the stability of mountain spruce stands in the Sudety Mountains and its effect on the dynamics of thickness growth. Conference paper, p. 221-231 (in Polish).

Tabatabai, M.A., Bremner, J.M., 1969. Use of $p$-nitrophenol phosphate for assay of soil phosphatase activity. Soil Biology and Biochemistry 1, 301-307.

Thelin, G., 2000. Nutrient imbalance in Norway spruce. Doctoral Dissertation, Department of Ecology, Plant Ecology, Lund University, Sweden, $50 \mathrm{pp}$.

Tyler, G., 1975. Haevy metals pollution, phosphatase activity, and mineralization of organic phosphorus in forest soil. Soil Biology and Biochemistry 8, 327-332.

Vacek, S., Bilek, L., Schwarz, O., Hejcmanová, P., Mikeska, M., 2013. Effect of Air Pollution on the Health Status of Spruce Stands: A case Study in the Krkonoše Mountains. Czech Republic. Mountain Research and Development 33(1), 40-50. https://doi.org/10.1659/MRD-JOURNAL-D-12-00028.1

Van Reeuwijk, L.P. 2002. Procedures for Soil Analysis, 6th edn. Wageningen: ISRIC.

Vavřiček, D., Samec, P., Šimková, P., 2005. Soil properties as component of predisposition factors of Norway spruce forest decline in the Hanušovická highland mountain zone. Journal of Forest Science 51(12), 527-538. https://doi.org/10.17221/4585-JFS

Veresoglou, S.D., Peñuelas, J., Fischer, R., Rautio, P., Sardans, J., Merilä, P., Tabakovic-Tosic, M., Rillig, M.C., 2014. Exploring continental-scale stand health - N:P ratio relationships for European forests. New Phytologist 202, 422-430. https://doi.org/10.1111/nph.12665

Vottová, D., 2003. Trends in sulphur and nitrogen deposition fluxes in the GEOMON network, Czech Republic, between 1994 and 2000. Water Air and Soil Pollution 150, 73-87.https://doi.org/10.1023/A:1026146723728

Waluk, J., 1973. Laboratory of soil mechanics. Wrocław University of Technology, 163pp.

Zottl, H.W., 1990. Ernährung und Düngung der Fichte (Nutrition and fertilization of spruce). Forstw Cbl 109, 130-137.

Zwoliński, J., 2003. Risk assessment of air pollution impacts on spruce forests in the Silesian Beskid Mountains. Forest Research Papers 951, 53-68.

\section{Właściwości gleb oraz stan odżywienia osłabionych drzewostanów świerkowych w Masywie Śnieżnika w Sudetach Wschodnich}

\section{Słowa kluczowe}

Deficyt magnezu

Drzewostany świerkowe

Gleby leśne

Sudety

\section{Streszczenie}

Proces rozpadu monokultur świerkowych zachodzi na dużych obszarach we wszystkich strefach wysokościowych terenów górskich w Polsce od lat 80-tych. Proces ten przyspieszył osiągając dramatyczne tempo w XXI wieku. Celem niniejszej pracy było określenie przyczyn znacznego osłabienia drzewostanów świerkowych w Masywie Śnieżnika w 2005 roku oraz ewentualnie zaproponowanie stosownego nawożenia uzupełniającego. Badania prowadzono w Sudetach Wschodnich w górnej części Masywu Śnieżnika, w Nadleśnictwie Lądek Zdrój gdzie drzewostany świerkowe charakteryzowały się zróżnicowanym stanem osłabienia. Próbki gleb i igieł zostały pobrane do podstawowych analiz laboratoryjnych. Silnie osłabione drzewostany świerkowe występowały na ubogich Haplic Podzols, wykształconych z gnejsów, wykazujących silny deficyt magnezu. Drzewostany świerkowe niewykazujące wyraźnych objawów osłabienia występowały głównie na Dystric Cambisols wykształconych z łupków łyszczykowych, które były lepiej zaopatrzone w magnez. Badanie gleb i igieł wskazują, że osłabienie drzewostanów świerkowych w Masywie Śnieżnika związane jest z deficytem magnezu, a gleby silnie osłabionych drzewostanów wymagają nawożenia magnezytem. 